\title{
Supply Side Aspects of Residential Housing for Low Income Earners in Kenya
}

\author{
Gayline Vuluku, ${ }^{1, *} \&$ James Gachanja ${ }^{2}$ \\ ${ }^{1}$ Macroeconomics Division, Kenya Institute for Public Policy Research and Analysis, PO Box \\ 56445-00200, Nairobi, Kenya \\ ${ }^{2}$ Infrastructure and Economic Services Division, Kenya Institute for Public Policy Research \\ and Analysis, PO Box 56445-00200, Nairobi, Kenya \\ *Corresponding author: Macroeconomics Division, Kenya Institute for Public Policy \\ Research and Analysis. PO Box 56445-00200, Nairobi, Kenya. Tel: 254-072-450-5089. \\ E-mail: gaylinevuluku@gmail.com
}

Received: August 20, 2014 Accepted: September 16, 2014 Published: September 29, 2014

doi:10.5296/rae.v6i3.6171ＵRL: http://dx.doi.org/10.5296/rae.v6i3.6171

\begin{abstract}
The need to have shelter is indispensable to humanity. Access to adequate and decent housing units decreases with the increase in population, scarcity of fixed assets like land, escalating house prices and the rising cost of living. The study uses time series data, 1980-2011, drawn from the Kenya National Bureau of Statistics to determine the factors that would be used to stimulate the low cost housing market in Kenya. The Instrumental Variable estimation technique is applied for this study using location specific factors for Mombasa and Nairobi. Regression results indicate unique results for the two towns. Whereas Nairobi had the lending rate, the cost of supply, the plinth area, labour and input cost index, inflation and the real interest rate being important in determining supply Mombasa reported the coefficient, cost of building a house, commercial bank rate and their lagged values as important factors in determining supply. At the same time inflation, treasury bill rate and plinth area were important in explaining supply of residential housing.
\end{abstract}

Keywords: Supply, Residential Housing, Low Income Earners, Kenya 


\section{Introduction}

\subsection{Background and study context}

In the global arena, shelter is recognized as one of the basic needs. The expectation is that lesser expenditure in housing by households accords them healthier diets, quality education to their children and the ability to meet other needs of life (Wadrip et.al. 2011). Consequently there will be improved standards of living, increased spending leading to expansion of businesses and direct/indirect employment creation. While housing is a durable good, the ability of households to access it in an adequate and decent environment without compromising other needs has been found to have a lot of economic benefits which accrue to the citizens, business community and the government (Wood, 2004). For this reason, governments make an effort to ensure housing needs of the population are met. Usually, these governments mainly focus on how to meet the housing needs of low income earners who face financial limitations whether inform of income flows or access to credit. However, much more needs to be done in order to address the increasing deficit in low cost housing supply.

The monetary value of a house and its slow depreciating nature makes it the largest share of investment for households (World Bank, 2011). However house ownership has become an elusive dream for majority of Kenyans who cannot even afford rent in formal housing systems. As a result, most urban dwellers resort to settling in informal settlements which lack in construction fabric, basic infrastructure and security. Whereas some households choose to settle far away from their places of work spending long hours commuting and have inadequate social infrastructure. Never the less, they enjoy cheaper housing and cleaner environment.

The Kenyan legal notice no. 115, VAT remission Act, of 2008 defines persons earning less than a gross income of thirty five thousand shillings per month as low income earners in the housing context. Some of the characteristics associated with this group include: low income levels from informal employment, poor living conditions in crowded settlements with no basic infrastructure and informal housing systems.

Whereas in housing markets, market failure is a common phenomenon, one of the explanations has been lack of efficient market allocation (Oxley \& Smith 1996). Secondly, the fact that consumers act in their own self-interest sometimes leads to externalities (Maclennan, 1982). In the past, several efforts have been made to provide shelter to the low income groups in Kenya. To begin with, site and service schemes were introduced in the early 1980s, with funding from International Monetary Fund, to cater for low income earners in provision of housing and the accompanying infrastructure. The programme met only 10 per cent of the low income urban demand and was often not affordable to low income earners resulting to informal settlement growth in urban Kenya (United Nations, 2011). However, the approach to shelter provision changed in the late 1980s through adoption of the enabling approach because it was thought that market failure was attributed to excess government intervention. Under the enabling approach, the government is tasked with providing legal, institutional and regulatory framework while the private sector, non-governmental organizations and individuals produced housing units. But, lack of coordination between the 
government and the other players led to failure of programmes like housing through cooperatives. For instance, between 1980 and 1999 out of the 418 registered cooperatives with memberships of 30,000; less than 1000 registered housing units were produced (ibid).

Worsening housing conditions motivated revision of the housing policy through Sessional Paper No.3 of 2004 on National Housing Policy for Kenya which came in place to replace Sessional paper no.5 of 1969. The later followed a strategy of aided self-help and co-operatives while the former focuses on partnerships and participation of all stakeholders guided by their comparative advantage (Government of Kenya, GoK, 2004). The current policy recognizes the gap in supply and demand of housing and seeks to implement strategies to encourage formal and informal private sector participation. Today, most of the objectives in the policy are yet to be met from facilitating increased supply to incentives meant for developers.

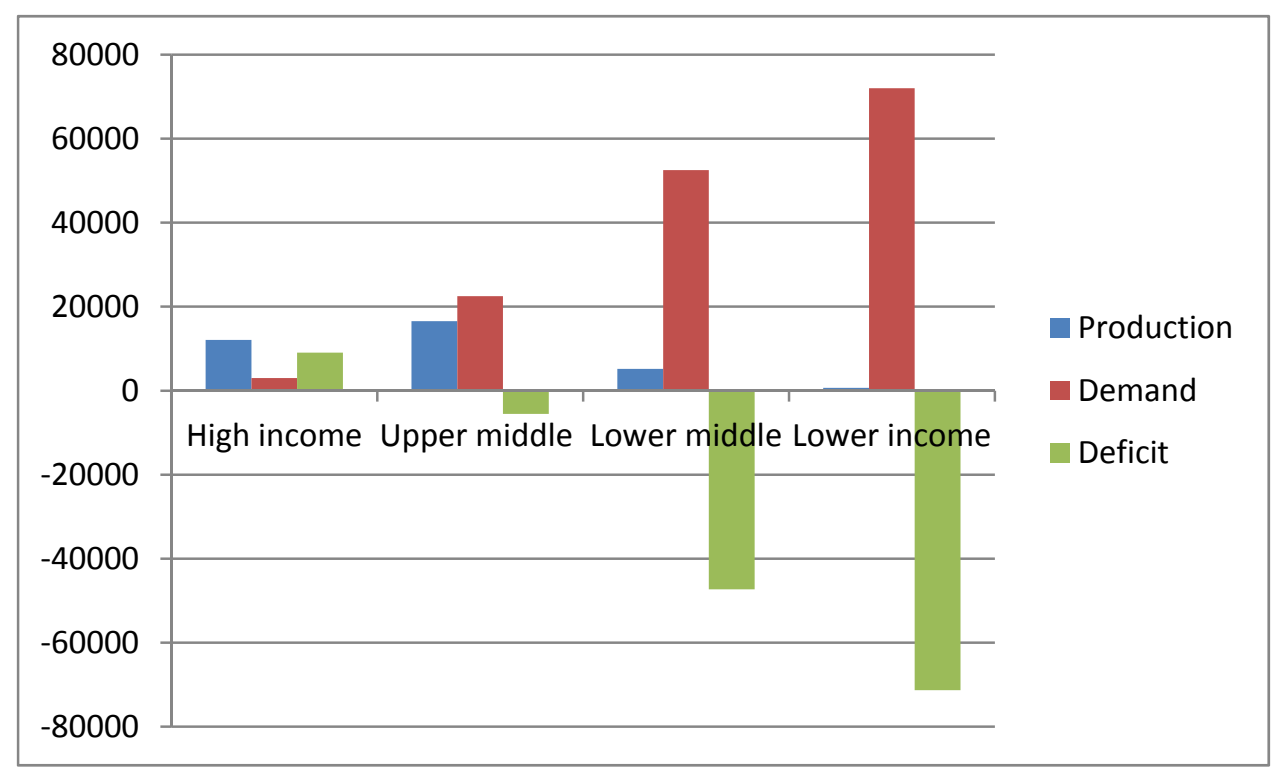

Source; (GoK, 2007)

Figure 1. Supply of housing to different income groups in urban Kenya

Contrary to government efforts and initiatives, a look at the supply statistics as at 2008 (see, figure 1) indicate that supply of housing is biased towards the high income group which enjoys a 60 per cent supply surplus. While the upper middle, lower middle and lower income groups suffer 15 percent, 92 percent and 98 percent deficits respectively (GoK, 2007).

Whereas the population grows at a rate of 3 percent per annum urbanization is growing at a faster rate of 4.5 per annum (GoK, 2013). As at 2008, 59 percent of urban residents lived in single roomed dwelling units (GoK, 2007). The ratio of housing units to population in urban areas is 6.49 against a prescribed 5 while rural Kenya report less congestion with a ratio of 3.08 persons (GoK, 2011). It is then evident that if supply of low cost housing is not accelerated pressure will further be exerted on the already few housing resources with market forces pushing prices beyond the reach of low income earners. Consequently, informal settlements which are lacking in adequate space, basic infrastructure and construction fabric 
will continue growing. In addition, poor living conditions directly affect the productivity of the labor force, efficiency, quality of life, health and competitiveness of cities resulting into slower economic growth (Giddings, 2007). It is therefore imperative that housing production is aligned to the prevailing household income levels. The study thus aims to determine economic factors that would enhance supply of low cost housing, estimate how zoning and planning regulations affect housing and examine if location affects housing supply.

\section{Literature review}

\subsection{Theoretical literature review}

The urban spatial theory postulates that the flow of new construction is equated to the growth in population. Land prices are based on the stock of housing as opposed to the level of building activity. Therefore, increased house prices initially generate huge returns but the housing output increases temporarily above some normal level. As the stock of units increase, land prices follow suit and eventually absorb the excess returns forcing construction to adjust downwards to its normal level (Dipasquale, 1994).

Secondly, the Ricardian rent theory makes the assumption that land is fixed and a single product; say a house is produced in the available land. Keeping in mind the fixed supply of land, demand for land is derived from the demand for housing where the equilibrium in the market between demand and supply fixes the land price. The theory concludes that the price of land is high because the price of housing is high and not the vice versa. The neoclassical theory on the other hand views the production process using land as an input rather than income distribution. The theory proposes that land has many uses as a factor of production and rational producers follow the most profitable use (Meen, 2001).

Thirdly, the classical price theory assumes a competitive market where prices are determined by forces of demand and supply with no government intervention in price determination. The quantity supplied in a market is the amount of goods that sellers are willing to produce and sell under given circumstances. These include; the cost of inputs in the production process, the cost of labor, the price of capital, technology and expectations of future prices. Supply would then imply the relationship between quantity supplied and the price of the good ceteris Paribus. The law of supply states that when the price of a good rises and everything else remains the same, the quantity of goods supplied also rises. There is therefore a direct relationship between supply and price.

The housing market can therefore be conceived in the same way as the market for any other good which is competitive in nature. A house is thus a private good to which the owners have control over. However, it can be viewed as a merit good which cannot be left purely to the market for ethical and political reasons (Oxley \& Smith, 1996). At the same time, governments influence the housing market through policy. This is mainly because the housing market is prone to market failure since conditions necessary for efficient market allocation do not exist as consumers act in their own interest due to effects of externalities (Maclennan, 1982). Increased output of housing units implies increased price, since price and supply have 
a direct relationship. If housing supply is inelastic new construction in the market is negatively related to input price. In the housing market, inputs are combined by supply side agents to produce housing services. Relative prices may encourage producers in the housing market to increase supply or not and suppliers of input to increase or reduce input production to this sector. Entry into the production process has little barriers with the main constraint lying in the input supply process Mayo, Malpezzi and Gross (1986). Additionally, government regulations may restrict competitive input allocation say finance (ibid).

\subsection{Empirical literature on supply of housing}

Gross domestic product, population and real property gains tax are positively correlated with housing prices in Malaysia (Ong, 2013). Additionally other studies in the same country have found that GDP is linked to activities in the housing market with fluctuations in GDP having a significant relationship with house prices. While an increase in population leads to increase in the demand for housing which in turn increases the prices of housing units. It is also noted that the real property gains tax is inversely related to house price where the relationship is found to be significant, whereas interest rates had no significant relationship to house prices.

Real interest rates and expected inflation rates have a significant negative influence on new housing construction with a huge magnitude that would not simply imply the cost of capital or holding costs whereas cost of construction is found to have no effect on housing starts (Topel \& Rosen, 1988). To reach this conclusion the authors use an adjustment cost model and IV estimation on a twenty five year time series data of the United States. Factor prices are found to be correlated with the level of new constructions and positively correlated with relative prices of housing. Additionally, according to Disquale and Wheaton (1994), long run increase in house prices results in a permanent increase in construction with its magnitude determined by increased factor prices caused by increase in new construction (as cited in Disquale, 1999). However studies have found the use of consolidated national data may not paint a true picture since regional factors may affect housing supply uniquely (Ansah (2012); (Wang et.al. (2012).

Mayer and Somerville (2000) did a study on the relationship between land use regulation and new residential construction using quarterly panel data from 44 metro areas. Findings suggest that land use regulation lowers the level of new constructions with highly regulated metro areas having up to 45 percent lower starts and price elasticity's of up to 20 percent lower than those of less regulated areas. Whereas regulations that lengthens and delays the development process affects new construction. Financial regulations' have less impact on new construction. On the other hand, the cost of construction had no impact on supply of housing (Disquale \& Wheaton, 1999); (Phang, 2010).

A study of metropolitan specific price elasticity of supply of housing and their sources using time series data was done by Green, Malpezzi and Mayo (2005). The authors regress population density, marginal tax rate, house price and property tax. Findings confirm that population levels, density and regulatory environment are important in explaining supply elasticity while land use regulation leads to lower supply elasticity. 
A case study on Aberdeen, United Kingdom by Ansah (2012) modeled the supply of new residential construction for local housing markets. Using time series data, structural form model and IV approach; housing starts are estimated as a function of changes in house price as opposed to price levels and other cost shifters to analyze their impact on price elasticity. The results indicate changes in the house price having a large positive coefficient of 3.7 per cent in the basic model while increase in building warrants granted increased housing starts by approximately 0.03percent. Changes in raw material cost and interest rates are found to be insignificant giving the importance of local as opposed to national housing supply measurement. Supply elasticity illustrated that developers in Aberdeen respond more to a change in house price by initiating new construction. In contrast Kenya has been experiencing increased demand of low cost housing but supply has remained low. It is thus paramount to establish if the market responds to demand with more supply or higher prices and if it is supply, to what income group.

Grimes and Aitken (2010) did a study using panel data from for 73 administrative regions in New Zealand. Using the Tobin's q specification they modeled housing supply, land cost and price adjustments. The empirical results indicate that high housing supply elasticities help in containing price changes caused by housing demand shocks. The increase in land price was found to be moderate as compared to the increase in house price and construction costs. The authors conclude that there is an interrelationship between supply of housing and house price dynamics.

According to Manheim, (2008) increased economic activity; short term interest rates and construction cost positively affect housing prices. Nevertheless, the adjustment process takes some years in case of a deviation from the long term equilibrium. Much as the findings were consistent when different equations and methods were applied, variations are observed for each particular country which can be attributed to differences at the countries micro level characteristics. The author reached the conclusion by running a panel cointegration analysis for 15 countries over a period of 30 years and an error correction model to determine the speed of adjustment after a shock.

Residential construction cost and region specific factors like demographics are found to significantly influence housing supply negatively. This is according to a study by Liu and London (2011) on the relationship between new housing supply and residential cost with regional differences in Australia. The authors use panel data and the error correction model for their estimation. On the other hand, Tu, (2000) using national and sub national time series data found that national house price models cannot represent the sub national price models. Thus, modeling the housing markets on a regional level without regional heterogeneities is not realistic.

Using time series data and employing two stages least square regression analyses, Vermeulen and Hilber (2010) did a study on the impact of restricting housing supply on house price and affordability in England. Measuring supply constraints that included availability of developable land regulation and physical restrictions they found that regulation and physical constraints render housing market more volatile by raising the sensitivity of prices to demand 
conditions. OLS results show that house prices deviate from the mean by 43 percent while a one standard deviation increase in developable land developed raises the house price by 2.0 percent and elevation range affects long term volatility negatively.

\section{Research Methods and Procedures}

\subsection{Model specification}

The equation to be estimated consists of; the number of units supplied (SN) as an independent variable and is a function of input cost index (ICI), labour cost index (LCI), cost of capital (CBR and TBR) which is expected to be zero if capital is drawn from savings, population (POP), the total cost of supply (SC), inflation (INFLA) and plinth area (PA). We use GDP per capita to represent income and the demand side of the model. Location specific variables i.e. SC, SN, POP and PA are drawn from Mombasa and Nairobi whereas the rest of the variables are nationally representative.

Numbers of housing units supplied to the market are allowed to vary depending on the factors that are specific to the two towns. Following Ansah (2012) we specify the housing units' completed in a given year (SN) as a function of the current and past cost of supply and other cost shifters.

$$
s n=f(p o p, c b r, t b r, p a, s c, i c i, l c i, g d p, \text { infla })
$$

In the second model we introduce the lagged variables to the three models i.e. Nairobi, Mombasa and the pooled data set and represent them as;

$$
s n=f\left(p o p, c b r, t b r, p a, s c, i c i, l c i, g d p, \text { infla }, s c_{t-1}, i c i_{t-1}, \text { infla }_{t-1}, c b r_{t-1}, t b r_{t-1}\right) \ldots . .
$$

The third model includes the lagged variable of the supply number to see if the past construction numbers affect the current supply.

$$
s n=f\left(p o p, c b r, t b r, p a, s c, i c i, l c i, g d p, \text { infla }, s c_{t-1}, i c i_{t-1}, \text { infla }_{t-1}, c b r_{t-1}, t b r_{t-1}, s n_{t-1}\right) \ldots \ldots
$$

\section{Results and discussion}

\subsection{Test for stationarity of the data}

The study uses the Augmented Dickey Fuller and Phillips Peron test, which makes the assumption of unit root presence in the null hypothesis, to test for the stationarity of variables. Location specific variables are plinth area, population, supply cost and supply number. The rest of the variables remain the same irrespective of the location.

Labour cost index, input cost index, inflation, commercial bank rate, and the Treasury bill rate were integrated of order 0 ; I (0). The number of housing units supplied (SN) in Nairobi was integrated of order 1 whereas the variable was stationary at level in Mombasa i.e. I (0). The gross domestic product per capita, plinth area, population, supply cost and supply number were integrated of order one; I (1). All the variables had significance levels above 95 percent. When we combine the two locations, four variables that change with location i.e. 


\section{Macrothink}

Research in Applied Economics

ISSN 1948-5433

2014, Vol. 6, No. 3

plinth area, population, supply cost and supply number are found to be integrated of order 1.

\subsection{Regression results using the IV approach}

The regression analysis was carried out separately for Nairobi and Mombasa then pooled together for the two towns to find out if location has an impact on the supply of residential housing units. The results are presented in table 1 with the model explaining 86 percent of the variations in the supply of residential housing units for Nairobi, 59 percent for Mombasa while the pooled data has 88 percent explained. The intercept which represents what explains the supply numbers if all the explanatory variables included in the model are zero is found not important in Nairobi and the aggregate model. For Mombasa though; the intercept is important in explaining residential housing supply implying that an important variable affecting the market in Mombasa was not estimated.

\subsection{Factors that influence residential housing supply in Nairobi}

From table 1, the cost of supply(Note 1) for Nairobi was found to be important in explaining the number of residential housing units supplied to the market with its coefficient being significantly different from zero at 1 percent significance level. This is contrary to findings by authors reviewed (Mayer \& Somerville, 2000; Disquale \& Wheaton 1999; Muth, 1960; Phang, 2010) which could be explained by the context of the studies i.e. mainly European economies. Unlike the local market which experiences high cost of capital as indicated by commercial bank interest rates and the low access to financial services the cost of capital is lower in European economies.

The Treasury bill rate is observed to be important in explaining the volumes of supply to the market. This implies that the real cost of capital influences the decision to supply and this is inversely related to the number of housing units supplied. If the real cost of capital was not so high we then expect to see more residential houses in the market. Additionally, the commercial bank rate is found to be important in explaining the residential supply market. This is contrary to a study by the World Bank and Central Bank on, Mortgage Finance in Kenya, where the source of funds for real estate market in Kenya could not be attributed to the mortgage loan book. We can therefore conclude that those firms/people who qualify to get mortgages make maximum use of the service and transmit the cost to the end user whether through renting or selling. 
Table 1. Regression results for Nairobi, Mombasa and aggregate for Nairobi and Mombasa

\begin{tabular}{lllllll}
\hline & Nairobi & \multicolumn{3}{c}{ Mombasa } & \multicolumn{3}{c}{ Nairobi and Mombasa } \\
\cline { 2 - 7 } Variable & Coefficient & T-Statistic & Coefficient & T-Statistic & Coefficient & T-Statistic \\
\hline ICI & $-0.8395 * * *$ & -3.9756 & -0.100524 & -0.977937 & $-0.80697 * * *$ & -4.4063 \\
D(SC) & $0.02482 * * *$ & 3.2211 & $0.392445 * *$ & 2.044760 & $0.01967 * * *$ & 3.0514 \\
CBR & 38.17353 & 1.62049 & $-21.43844 *$ & -1.870286 & 25.5852 & 1.2832 \\
D(GDP) & $-0.03967 * *$ & -2.1918 & 0.007422 & 0.763412 & $-0.02906 *$ & -1.9548 \\
LCI & $0.92564 * * *$ & 3.7116 & 0.102631 & 0.854570 & $0.90270 * * *$ & 4.1611 \\
D(PA) & $-1.24701 * * *$ & -2.65748 & 0.925157 & 1.298283 & -0.571030 & -1.5263 \\
D(SC(-1)) & -0.013148 & -1.354421 & $0.328883 *$ & 1.987330 & -0.011306 & -1.3924 \\
ICI(-1) & 0.016178 & 0.545086 & 0.005807 & 0.408728 & 0.012176 & 0.4834 \\
D(POP) & $0.00132 * * *$ & 3.210664 & $0.003033 *$ & 1.743570 & $0.00074 * *$ & 2.3580 \\
TBR & $-39.0179 * * *$ & -4.53929 & -1.225330 & -0.291182 & $-33.8992 * * *$ & -4.6562 \\
INFLA & $27.5781 * * *$ & 4.573809 & -1.133282 & -0.370395 & $24.98093 * * *$ & 4.8656 \\
TBR(-1) & -17.24847 & -0.728123 & 20.36057 & 1.663507 & -18.85496 & -0.9400 \\
CBR(-1) & -2.140432 & -0.295952 & $7.381324 *$ & 1.937965 & 4.382060 & 0.7169 \\
INFLA(-1) & $14.35554 * *$ & 2.171011 & 5.223199 & 1.446557 & $22.14154 * *$ & 3.9753 \\
C & -95.90268 & -0.588171 & $167.4645 *$ & 1.937735 & -99.60042 & -0.7128 \\
R ${ }^{2}$ & 0.8664 & & 0.5983 & & 0.8825 & \\
Adj. R ${ }^{2}$ & 0.7418 & & 0.2234 & & 0.7729 & \\
\hline & & & & &
\end{tabular}

$* * * * * *$ Significance level at $1 \%, 5 \%$ and $10 \%$ respectively

Input cost(Note 2) index and labour cost index are important in explaining supply of residential housing. Besides being statistically significant, the input cost index is found to be economically important in explaining the residential housing units supplied to the market. The relationship is inverse implying that if the input cost is high we expect lesser units in the market and vice versa. Assuming standard inputs used in the construction process are of the same quality for instance cement, sand, bricks or machine cut stones, we expect the cost of input material to be the same irrespective of the market segment one is building for. The difference may come in the fittings and accessories which are only a fraction of the input cost index. This therefore implies that irrespective of the supply market, cost is important in determining supply and so the same applies to low cost housing. Inflation rate is significantly different from zero at 1 percent significance level. This is consistent to the input and labour cost indexes as well as supply cost which are directly affected by inflation.

GDP per capita which the study uses as a proxy for income is observed to be important in explaining the supply of residential housing. The finding is consistent with other studies (Ong, 2013) and economic theory whereby consumption of goods is limited by the budget 
constraint and so is housing. The population level is found important in explaining the supply numbers. This may be informed by the fact that housing construction is intended for a target population and so it is expected that their known numbers affect supply. Finally, plinth area has a coefficient inversely related to the numbers supplied implying that if the plinth area increases we expect fewer units to be supplied in the market. Again the variable is significantly different from zero in explaining the housing units supplied to the market. We thus conclude that zoning regulations that dictate the minimum land size, plot ratio and ground coverage for housing construction are important in explaining supply to the market.

\subsection{Factors that influence residential housing supply in Mombasa}

The regression results for Mombasa are observed to be statistically different from those of Nairobi. In the first model, with one lag period, supply cost and its lagged variable, commercial bank rate and its lagged value and population were found to be important in explaining residential housing supply. At the same time, the constant is found to be statistically significant and important in explaining the supply of residential housing. This implies that there are variables which are important in explaining the housing market in Mombasa but were not measured in this study. Some of the variables may include the regulatory and institutional frame work and the geographical attributes which were beyond the scope of the study due to data availability.

Additionally, other cost shifters i.e. treasury bill rate, input cost index and labour cost index were not important in explaining supply of housing units in Mombasa contrary to the findings in Nairobi. The same results are reflected in the importance of inflation in influencing the market. According to the Quantity Surveyor Journal (October - December 2013) the input material costs for Mombasa are observed to be significantly lower than those of Nairobi. The location specific endowments may explain the significant differences between the two towns. Besides, the education levels for residents have been reported to be low coupled with high unemployment rates (GoK, 2010) and so it may be easy to access cheap menial labour and lower the construction cost significantly.

\subsection{Two lag periods included for endogenous variables}

Table 2 indicates the factors that were found to influence supply of housing units when the endogenous variables were lagged for two time periods. To begin with; the results for Nairobi only change marginally with the commercial bank rate and the lagged supply cost observed to be important in explaining residential housing supply as well. However, the $\mathrm{R}$ squared is observed to be lower implying that the model is best fit with one lag period; 86 percent to 84 percent. 
Table 2. Regression results for Nairobi and Mombasa - two lag periods

\begin{tabular}{|c|c|c|c|c|}
\hline \multirow[b]{2}{*}{ Variable } & \multicolumn{2}{|l|}{ Nairobi } & \multicolumn{2}{|l|}{ Mombasa } \\
\hline & Coefficient & T-Statistic & Coefficient & T-Statistic \\
\hline ICI & $-0.737773 * * *$ & -3.383685 & -0.070128 & -0.661593 \\
\hline $\mathrm{D}(\mathrm{SC})$ & $0.037608 * * *$ & 4.298283 & 0.107722 & 0.658411 \\
\hline CBR & $33.58748 * * *$ & 3.675574 & -3.346303 & -0.740293 \\
\hline $\mathrm{D}(\mathrm{GDP})$ & $-0.057116^{* * *}$ & -2.686584 & -0.008844 & -0.900412 \\
\hline LCI & $0.806582 * * *$ & 3.185486 & 0.082028 & 0.663140 \\
\hline $\mathrm{D}(\mathrm{PA})$ & $-1.389066^{* * *}$ & -2.733123 & $1.538166 * *$ & 2.078266 \\
\hline $\mathrm{D}(\mathrm{SC}(-2))$ & 0.116383* & 1.794085 & 0.189119 & 0.873916 \\
\hline ICI(-2) & 0.018513 & 0.839087 & $-0.017075^{*}$ & -1.767691 \\
\hline $\mathrm{D}(\mathrm{POP})$ & $0.000988 * *$ & 2.042060 & 0.000946 & 0.528698 \\
\hline TBR & $-31.26173 * * *$ & -3.577024 & 7.640687* & 1.928608 \\
\hline INFLA & $21.72041 * * *$ & 2.883787 & -4.688031 & -1.484248 \\
\hline TBR(-2) & 3.353513 & 0.377529 & -7.158240 & -1.638159 \\
\hline CBR(-2) & 4.448147 & 0.602984 & $6.505242 *$ & 1.811242 \\
\hline INFLA(-2) & $-12.03675 *$ & -1.708178 & $9.390020 * * *$ & 3.040076 \\
\hline $\mathrm{C}$ & -179.7555 & -0.938366 & $180.7805 * *$ & 2.222464 \\
\hline $\mathrm{R}^{2}$ & 0.8424 & & 0.6838 & \\
\hline Adj. $\mathrm{R}^{2}$ & 0.6849 & & 0.3677 & \\
\hline
\end{tabular}

Contrary, the results for Mombasa are different depending on the lag period. While supply cost and commercial bank rate together with their lagged values and population are important in explaining the supply of residential housing with only one lag, lagging the endogenous variables twice indicate that plinth area, input cost index, treasury bill rate Inflation and the constant are important in explaining supply of residential housing. Besides, the $\mathrm{R}$ squared increases from 59 percent to 68 percent.

Plinth area was however found to be important in explaining the housing units supplied to the market in both towns. This is an indicator that the zoning regulations which stipulate the ground coverage, plot ratio and minimum land subdivision are important. Whereas the housing Act, 2011 stipulates the minimum plinth area of 30 square meters a revision may be necessary to meet the market realities and zoning regulations that allow for more floor areas adopted.

From these findings the study concludes that land plays a major role in stimulating supply of housing as observed by Follain, (1999). At the same time inflation and the cost of capital are factors considered by developers in making investment decisions. 
Table 3: Regression results for Nairobi, Mombasa and an aggregate for both cities with the dependent lagged variable included

\begin{tabular}{lllllll}
\hline & Nairobi & \multicolumn{3}{c}{ Mombasa } & \multicolumn{2}{c}{ Nairobi and Mombasa } \\
\cline { 2 - 7 } Variable & Coefficient & T-Statistic & Coefficient & T-Statistic & Coefficient & T-Statistic \\
\hline ICI & $-0.8471^{* * *}$ & -4.06095 & -0.108042 & -0.920845 & $-0.7982 * * *$ & -4.226667 \\
D(SC) & $0.0308^{* * *}$ & 3.36404 & 0.088941 & 0.531357 & $0.0222^{* *}$ & 2.607805 \\
CBR & 37.21177 & 1.59894 & -4.051276 & -0.868871 & 24.6061 & 1.196385 \\
D(GDP) & $-0.0424 * *$ & -2.35311 & -0.003253 & -0.267749 & $-0.0310^{*}$ & -1.964398 \\
LCI & $0.9498^{* * *}$ & 3.84417 & 0.125386 & 0.918733 & $0.8973 * *$ & 4.024134 \\
D(PA) & $-1.2184 * *$ & -2.62640 & $1.504827 *$ & 2.004035 & -0.5681 & -1.479324 \\
D(SC(-1)) & -0.010627 & -1.08213 & 0.186281 & 0.849638 & -0.0097 & -1.087798 \\
ICI(-1) & 0.017051 & 0.58170 & $-0.021044 *$ & -1.919014 & 0.0129 & 0.500490 \\
D(POP) & $0.0012^{* * *}$ & 2.95053 & 0.001712 & 0.835683 & $0.0007 * *$ & 2.281557 \\
TBR & -28.64672 & -2.34242 & $9.883156 *$ & 2.020366 & $-31.257 * * *$ & -3.376184 \\
INFLA & $25.818^{* * *}$ & 4.20648 & -5.956218 & -1.668767 & $24.8520 * * *$ & 4.709268 \\
TBR(-1) & -20.98044 & -0.88890 & -6.530620 & -1.452798 & -18.99964 & -0.922662 \\
CBR(-1) & -3.083060 & -0.42906 & $6.745244 *$ & 1.847710 & 3.886645 & 0.611312 \\
INFLA(-1) & $13.6020 * *$ & 2.07350 & $10.004 * * *$ & 3.105633 & $21.8679 * * *$ & 3.806031 \\
D(SN(-1)) & -0.250797 & -1.17781 & -0.282443 & -0.801758 & -0.0919 & -0.483367 \\
C & -146.3933 & -0.87872 & $224.9474 *$ & 2.269482 & -113.1855 & -0.774390 \\
R $^{2}$ & 0.8785 & & 0.6987 & & 0.8845 & \\
Adj. R & 0.7483 & & 0.3511 & & 0.7607 & \\
\hline
\end{tabular}

$* * *, * *, *$ Significance level at $1 \%, 5 \%$ and $10 \%$ respectively

Results in table 3 include the lagged dependent variable, supply number, to analyze whether past output affects the current number of residential housing units produced.

The results show that past housing units completed do not explain current housing units supplied to the market in both towns when regressed separately. Additionally, the lagged number of units supplied is not important when the data for the two towns is pooled. This could be explained by the fact that there could be many housing units supplied to the market each year which are consumed on delivery. At the same time new demand arises from the ever increasing population and new household formations. Besides if households are the builders we expect this to be a one off activity by them.

Again we notice that depending on the location, variables behave uniquely. Consistent with the regression results without the lagged dependent variable, the commercial lending rate, the cost of supply, input cost index, labour cost index, inflation and population at levels are important in explaining supply for Nairobi and the pooled data as opposed to Mombasa where these are not important. Whereas the plinth area remains important for the independent 
models only emphasizing the role played by zoning regulation in influencing the residential housing units supplied at the local level.

\section{Conclusion and policy recommendations}

\subsection{Conclusions}

Low income earners in Kenya find it not only expensive to build or buy a house but also to pay rent in formal housing systems. As a result over 80 percent of residents in urban Kenya live in informal settlements which lack in sanitation, space, basic infrastructure and waste disposal system (World Bank, 2011). This study sought to find ways of stimulating the supply of residential housing to low income earners in Kenya.

The findings suggest that depending on the location, the factors that affect supply of housing differ. However the plinth area and cost of capital, Treasury bill rate or commercial lending rate, are consistently important in explaining the number of units supplied to the market for the sample towns of Mombasa and Nairobi. The study thus concludes that the land size on which the house sits is an aspect that can be used to change the entire housing market for better. At the same time, the target population for residential housing development plays an important role in determining supply. In addition to that, the cost of capital represented by the treasury bill rate and commercial lending rate is important in explaining the housing market. This affirms the fact that a housing unit, in most cases, forms the largest investment for households and requires huge capital investment. Many a times, households end up borrowing to finance the investment thus the importance of the cost of capital. For Nairobi and the aggregate dataset, besides the plinth area, GDP per capita and treasury bill rate, the study finds the supply cost, commercial bank lending rate, input cost index, labour cost index and inflation to be important in explaining the supply of housing units delivered to the market.

\subsection{Policy recommendations}

The building blocks for housing development include land, capital and the market. To begin with, land requires a significant amount of capital. At the same time most developers would need to borrow at a cost which goes further to increasing the capital requirement. Secondly the market which includes buyers and or tenants needs large sums of money for purchase or significant amounts periodically for lease. In case of purchase most buyers have to borrow to finance acquisition.

To ease this burden, the government should put in place partnerships between companies and financial institutions to finance low cost housing for employees, for instance if a new company is coming up, one of the requirements should be such an arrangement.

There is need to encourage the use of readily available alternative building material aside from the conventional while not compromising on quality. Awareness creation about the same should be enhanced through; advertisements, documentaries, social media and all other means available to disseminate the information. Households may not be aware about other 
innovative and cheaper alternative building materials, where and how to get them and at what cost. This could be explained by the fact that most developers/ home builders use the conventional materials which are expensive.

Similarly Public Private Partnerships should be promoted to allow for affordable end user pricing. The government could supply land and the private investor deals with putting up the structures. At the planning stage in urban areas let counties adopt mixed land use where proximity to social facilities, place of work and means of transport is considered. This will aid in reducing the escalating land prices as indicated by the importance of plinth area. Additionally, the county governments which are in the nascent stages of development should consider proper land use planning from the onset, to delineate and preserve public land for housing development. Together with forming land banks, land use planning will help the public sector with instruments to influence the housing market positively for low cost housing.

\section{Acknowledgement}

We would like to acknowledge and appreciate the financial support and training accorded by the Kenya Institute for Public Policy Research and Analysis (KIPPRA) to undertake this work. Special thanks to KIPPRA staff and the 2013/2014 Young Professionals cohort. We however remain liable to any errors or omissions.

\section{References}

Ansah O. W. (2012).Modelling the supply of new residential construction for local housing markets: the case of Aberdeen, UK. 19th Annual European Real Estate Conference, June 2012. Retrieved from http://web.sbe.hw.ac.uk/eres2012/PhD\%20Papers/eres2012_97.pdf

Dipasquale, D., \& Wheaton, W. C. (1994). Housing market dynamics and the future of housing prices. Journal of Urban Economics, 35, 1-27.

DiPasquale, D. (1999). Why Don’t We Know More About Housing Supply? Journal of Real Estate finance and Economics, 18(1), 9-23.

Follain, J. (1999). The price elasticity of the long run supply of new housing construction. Land Economics, 55, 190-199. http://dx.doi.org/10.2307/3146061

Giddings W. S. (2007). Housing challenges and opportunities in Sub-Saharan Africa. International Housing Coalition, Washington DC. Retrieved from www.intihc.org

Government of Kenya (2007). Kenya Vision 2030. Nairobi: Government Printer.

Government of Kenya (2010).The constitution of Kenya. Nairobi: Government Printer

Government of Kenya (2013). Economic Survey. Nairobi: Government Printer.

Government of Kenya (Revised edition, 2008). The Value Added Tax (Remission) (Low 
Income Housing Projects) Order, 2008), Nairobi: Government Printer.

Government of Kenya (Various), Statistical Abstracts, Nairobi: Government Printer.

Government of Kenya. (2004). The National Housing Policy Session paper no.3 of 2004. Nairobi: Government Printer.

Government of Kenya. (2011). Housing bill, Nairobi: Government Printer.

Government of Kenya, (2011). State of population 2011: Kenya's 41 million people: challenges and possibilities. Nairobi: National Coordinating Agency for Population and Development (NCAPD)

Green R. K., Malpezzi S., \& Mayo S. K. (2005). Metropolitan specific estimates of the price elasticity of supply and their Sources. The American Economic Review, 95(2), 334-339.

Grimes, A., \& Aitken A. (2010). Housing Supply, Land Cost and Price Adjustment. Real Estate Economics, 38, 325-53.

Institute of Quantity Surveyors of Kenya, 2013, the Quantity Surveyor April - June 2013, Vol. 015 issue 002

Liu, J \& London, K (2011). Analysing the relationship between new housing supply and residential construction costs with the regional heterogeneities. Australasian Journal of Construction Economics and Building, 11(3) 58-67.

Mayer J. C., \& Somerville T. C. (2000). Land Use Regulation and New Constructions. Journal of Regional Science and Urban Economics, 30(6), 639-662

Mayo S. K., Malpezzi S., \& Gross D. J. (1986). Shelter strategies for the urban poor in developing countries. The World Bank Research Observer, 1(2), 183-203

McLennan D. (1982). Housing Economics: An Applied Approach. Addison-Wesley Longman Limited.

Meen G. (2001). Modeling Spatial Housing Markets Theory, Analysis and Policy. (Advances in Urban and Regional Economics, Vol. 2, Kluwer Academic Publishers, Boston, 267 pp., ISBN 0-7923-7307-3

Ong T. S. (2013). Factors Affecting the Price of Housing in Malaysia. Journal of Emerging Issues in Economics, Finance and Banking, 1(5). Retrieved from http://www.globalbizresearch.com/images/files/73848_JEIEJB_\%20Tze\%20San\%20On g.pdf

Oxley, M., \& Smith, J. (1996). Housing Policy and Rented Housing in Europe (1st Ed.): London E\& FN Spon, an imprint of Chapman \& Hall.

Phang S. (2010). Affordable home ownership policy implications for housing markets. International Journal of Housing Markets and Analysis, 3(1), 38-52.

Topel R., \& Rosen S. (1988). Housing investment in the United States. Journal of Political 
Economy, 96(4), 718-740.

Tu Y. (2000). Segmentation of Australian housing markets: 1989-98. Journal of Property Research, 17(4), 311-327. http://dx.doi.org/10.1080/09599910010001420

United Nations Human Settlements Programme, (2011). Affordable Land and Housing in Africa. Vol.3. UNON, Publishing Services Section, Nairobi, Kenya.

Vermeulen W., \& Hilber C. (2010). The impacts of restricting housing supply on house prices and affordability. Department for Communities and Local Government. Queen's Printer and Controller of Her Majesty's Stationery Office. Retrieved from http://www.communities.gov.uk

Wang S., Chan S. H., \& Xu B. (2012). The Estimation and Determinants of the Price Elasticity of Housing Supply: Evidence from China. Journal of real estate research, 33(3). Retrieved from SSRN: http://ssrn.com/abstract=2144250

Wardrip K., Williams L., \& Hague S. (2011). The role of affordable housing in creating jobs and stimulating local economic development. Centre for housing policy. Retrieved from http://www.nhc.org/media/files/Housing-and-Economic-Development-Report-2011.pdf

Wood J. A. (2004). Economic Impact of Affordable Housing: New Construction, Rehabilitation and Assistance Programs. Salt Lake City, UT: Utah Housing Coalition

World Bank, (2011). Developing Kenya's mortgage market, Report No.63391-Ke. Washington DC. Retrieved from http://siteresources.worldbank.org/FINANCIALSECTOR/Resources/Kenya_Expanding _Mortgage_Finance_May_2011.pdf

\section{Notes}

Note 1. includes the total monetary value incurred in the delivery of a housing unit

Note 2. This refers to all the materials used in the construction process refer to Kenya's Statistical Abstract building and construction chapter

\section{Copyright Disclaimer}

Copyright for this article is retained by the author(s), with first publication rights granted to the journal.

This is an open-access article distributed under the terms and conditions of the Creative Commons Attribution license (http://creativecommons.org/licenses/by/3.0/). 